GLOSSARY

\title{
Indicators of socioeconomic position (part 2)
}

\section{Bruna Galobardes, Mary Shaw, Debbie A Lawlor, John W Lynch, George Davey Smith}

J Epidemiol Community Health 2006;60:95-101. doi: 10.1136/jech.2004.028092

This is the second part of a glossary on indicators of socioeconomic position used in health research (the first part was published in the January issue of the journal).

\section{OCCUPATIONAL BASED MEASURES (CONTINUED FROM FIRST PART OF THE GLOSSARY)}

British occupational based social class

(prior to 1990 known as the registrar general's social class)

Theoretical basis

The practice of classifying the population in Britain according to occupation and industry began as early as 1851 but it was not until the registrar's general's annual report for 1911 that occupation and industry were differentiated with a summary of occupations representing "social grades" separately presented. The main initial purpose was the analysis of fertility data, although mortality was also analysed; indeed there is evidence suggesting that revisions to the classification were constructed "in the light of knowledge of mortality rates". ${ }^{1}$

This scale is based on the prestige or social standing that a given occupation has in society. After revisions in 1990 this measure was more explicitly related to the skills needed to perform a particular occupation. ${ }^{1}$ It is widely used in Britain and in other European countries.

\section{Measurement}

Occupations are categorised into six levels or classes (table 1), ranked from higher to lower prestige, which can also be reduced to two broad categories of manual and non-manual occupations; a seventh category includes all people in the armed forces irrespective of their rank therein, which is generally excluded in health studies.

\section{Strengths and limitations}

A key strength of this measure is its past official status in Britain and hence its widespread use in vital statistics, as well as many population censuses and surveys over a long time period. Adaptations have been extensively used in other countries, making comparability between studies easier. However, a key limitation is the subjectivity of its theoretical basis. In addition, it does not account for recent changes in the occupational structure, such as the increase in service jobs and the decrease in unskilled and semi-skilled manual occupations, or the increasing number of women in the labour market. Based on these criticisms, the Office for National Statistics in the UK has since 2000 used the new
UK National Statistics socioeconomic classification as its official occupation classification (see below). Despite limitations the registrar general's social class system has been widely used to describe the socioeconomic gradient of health outcomes.

\section{Interpretation}

As (theoretically) a measure of prestige or social standing, it could be argued that the relation of this classification to health should be interpreted as due to the advantages bestowed by elevated social standing and increased prestige. In practice it is often interpreted as an indicator of both social standing and material reward and resources.

\section{The Cambridge scale lor CAMSIS, the Cambridge social interaction and stratification scale)}

Theoretical basis

This scale uses patterns of social interaction to determine the nature of social structure and a person's position within it; it is a hierarchical measure of social distance. The distance is defined by similarities in the lifestyles, social interactions, and resources that occupational groups share and is thus based on Weberian notions of what is important about social stratification. ${ }^{23}$ The scale was originally constructed by grouping occupations according to friendship, which gave a numerical indication of how similar (socially close) or dissimilar ( socially distant) any two occupations were. ${ }^{2}$

\section{Measurement}

The Cambridge scale provides a continuous measure that can be categorised into groups from the most to least advantaged (table 1). Although this classification bears resemblance to the registrar general's, its derivation (based on actual social networks rather than perceived status) means that some occupations will be differently classified by the two systems. ${ }^{2}$

\section{Interpretation}

The scale reflects general social and material advantage, and because it is based on social interaction it is also considered to represent lifestyles and health behaviours. ${ }^{2}$

Erikson and Goldthorpe class schema (also known as the Goldthorpe schema)

Theoretical basis

This classification is based on employment relations, classifying occupations that entail relations based on high levels of trust and independent working practices combined with delegated authority, to occupations based on a labour contract with very little job control. ${ }^{45}$ 
Table 1 Occupational based socioeconomic indicators: theoretical basis and group allocation

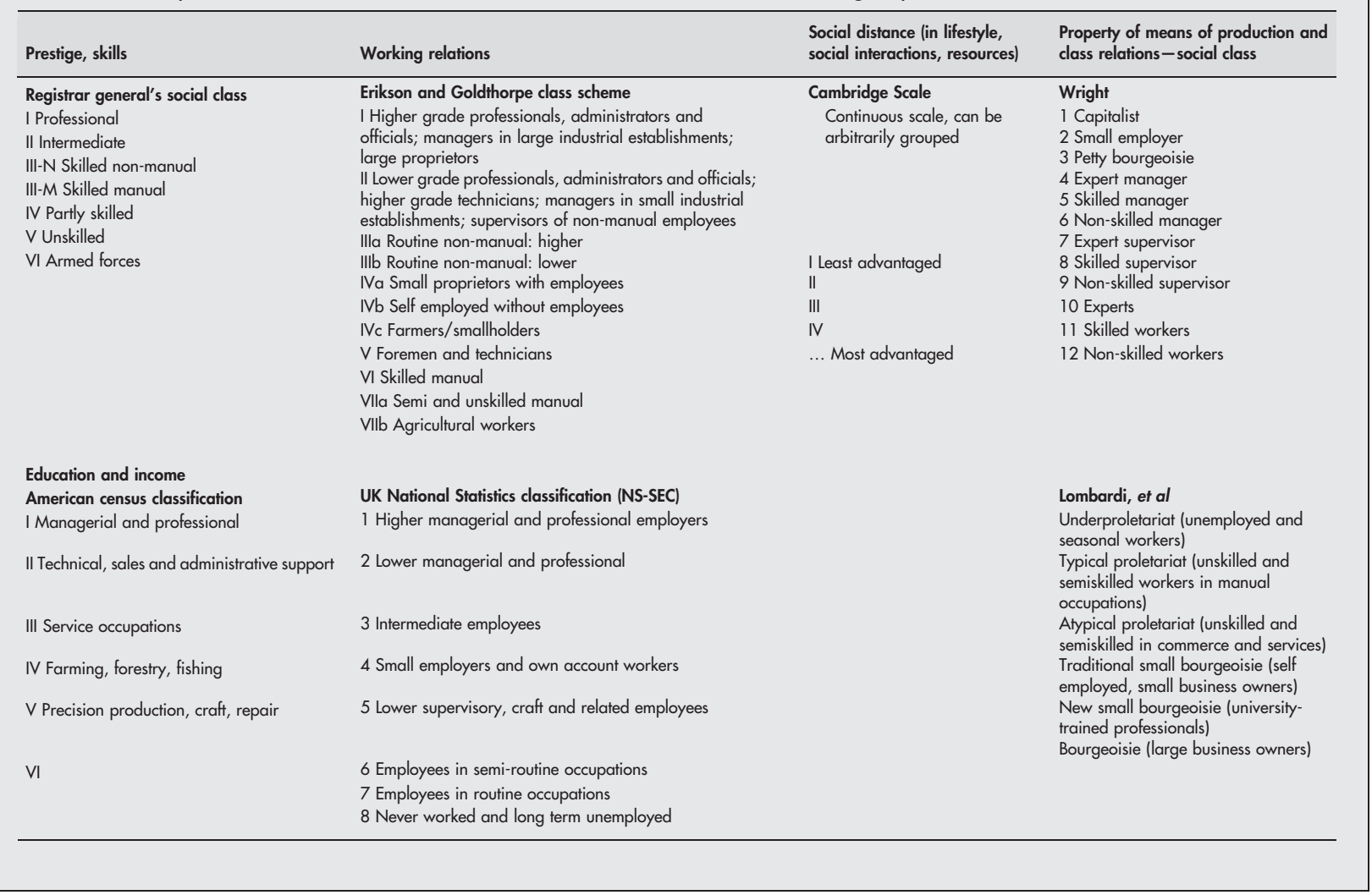

This scheme does not have an implicit hierarchical rank and therefore it does not necessarily capture a gradient in health across its groups. It has been used as an indicator of scioeconomic position in international comparisons of socioeconomic inequalities in health across Europe. ${ }^{6-8}$

\section{Measurement}

Occupations are classified into 11 groups. This classification is not a hierarchy (despite the numbering that is used to refer to each group) (table 1).

\section{Interpretation}

Differences in health outcomes between groups can be mainly attributed to differences in working relations and work autonomy; different contract and reward system terms of remuneration; and different job promotion prospects. ${ }^{4}$ However, the scheme also inherently reflects material resources as aspects of employment relations such as decision latitude are often co-terminus with material rewards accorded to different types of jobs. ${ }^{9}$

\section{Strengths and limitations}

This classification has a clear theoretical basis and it has been used in international comparisons. In addition, several studies have been conducted that permit assessment of its construct and criterion validity. However, working relations are likely to change over time and, therefore this scheme will also require continuous updating. ${ }^{10}$

\section{Marxist based social class classifications} Theoretical basis

These indicators are based on Marx's theory of class and therefore categorise people as to whether they are exploited workers or those who own the means of production. Strictly speaking, this is the correct interpretation of social class as first coined by Marx. However, in practice the terms socioeconomic position and social class are frequently used interchangeably in the epidemiological literature and the British registrar general's occupation based classification (although not based on Marxist theory) is referred to as social class. ${ }^{11}$

\section{Interpretation}

The results reported using these classifications in relation to health outcomes are explained in terms of exploitation between classes and in terms of the conflict generated by contradictory locations within this class system. ${ }^{12}$

To our knowledge there have been two explicit adaptations of Marx's theory of social class that take into account contemporary employment and social circumstances.

\section{(a) Wright's social class classification}

In this scheme people are classified according to the interplay of three forms of exploitation: (a) ownership of capital assets, (b) control of organisational assets, and (c) possession of skills or credential assets. This defines 12 locations (see figure 1) where cells 1 and 2 represent the capitalist class, cell 3 the petty bourgeoisie or self employed, cells 4 to 10 include contradictory class locations, and cells 11 and 12 the working class. People in the contradictory class locations belong simultaneously to the capitalist and the working class (capitalist in terms of controlling skills and credentials and exploiting workers; workers because they do not own capital assets and are controlled by capitalists). ${ }^{13}{ }^{14}$ In his later book, Wright uses variations of this classification. For example, in analysing time trends of the American class structure he used an eight location classification: employers, petty bourgeoisie, managers, supervisors, expert managers, experts, skilled workers, and workers. In a permeability analysis (analysis of friendship ties, family composition, and intergenerational 


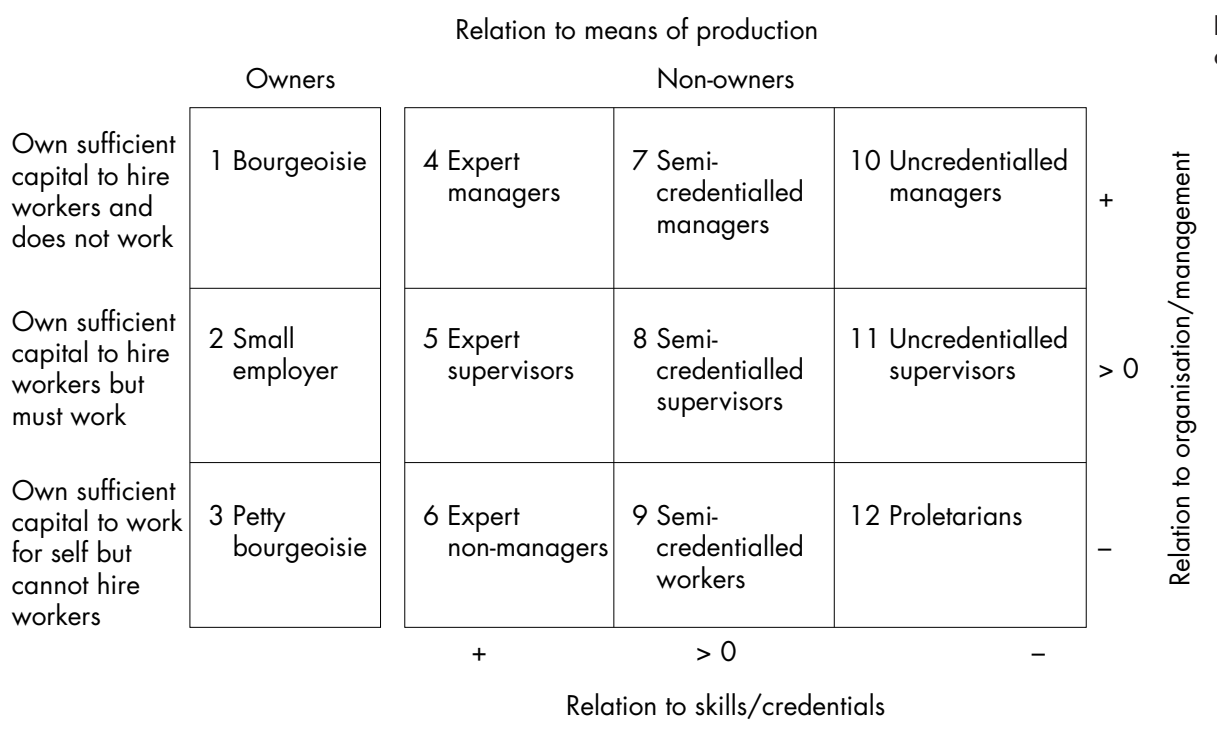

class mobility) Wright operationalises the social class classification in employers, petty bourgeoisie, experts managers, managers/supervisors, professionals, skilled workers, and workers. ${ }^{15}$ Some of these variations were driven by data availability and by theoretical reasons, as was the case for a different operationalisation of the skill dimension in the permeability analysis. ${ }^{15}$

In the USA, Muntaner et al, ${ }^{16}{ }^{17}$ Schwalbe and Staples, ${ }^{18}$ and Krieger et al ${ }^{11}$ have used Wright's classification in epidemiological research. Among others, Wright's social class scheme has also been used in studies conducted in Spain ${ }^{12}$ and in Israel. ${ }^{19} 20$ Macleod et al, in the UK, have applied Wright's notion of contradictory class location to investigate the role of material circumstances versus perceived social status on health. ${ }^{21}$

\section{(b) Lombardi et al social class classification}

The other social class indicator based on Marx's theories originated in Brazil. ${ }^{22}{ }^{23}$ Similar to Wright's classification, it highlights new contradictory categories of skilled people working for a salary but being in the position to exploit other workers, as well as the increasing proportion of people working in the commerce or service sector who may also be both exploiters and exploited. It classifies occupations into six groups (table 1).

\section{Other occupation based classifications}

There are a number of country specific occupation based classifications based on combinations of occupation, education and/or income information, or of adaptations of the UK registrar social class classification. ${ }^{24}$ They have often been developed in national statistical offices and are used in census and survey information originating within each country. ${ }^{25-27}$ As an example, the Edwards' socioeconomic scheme is used in the US census and in North American studies. $^{28}$ It is based on the educational and income level required for each occupation and is thus similar (at least in terms of interpretation) to the British registrar general's scale (table 1). It classifies occupations into 13 categories that are often collapsed into a smaller number of major socioeconomic groups. ${ }^{29} 30$

In addition, readers are directed to earlier reviews for more complete descriptions of measures that are less commonly used in contemporary epidemiological research, for example, the Nam-Powers classification, Siegel's prestige scale, and Treiman's standard international occupational prestige scale. ${ }^{28}$
Figure 1 Wright's social class classification.

\section{UK National Statistics socioeconomic classification (NS-SEC)}

From 2000 the UK NS-SEC has replaced the registrar general's social class and another official classification, socioeconomic groups SEG (for details on the history, process, and conversion between these schemes consult the UK National Statistics web page http://www.statistics.gov.uk/ methods_quality/ns_sec/default.asp). The NS-SEC is now used in all official statistics and surveys in the UK.

\section{Theoretical basis}

The NS-SEC is explicitly based on differences between employment conditions and relations, similar to the Erikson and Goldthorpe class schema. ${ }^{31}$ People are placed in groups according to occupations with different employment relations and conditions-such as whether they have a wage rather than a salary, their prospects for promotion, and levels of autonomy.

\section{Measurement}

Occupations are usually grouped into 7, 5, or 3 (plus an additional category of "never worked and long term unemployed") (table 1). Only the grouping that collapses into three categories can be considered as hierarchical.

\section{Interpretation}

The direct interpretation of this association would be that the conditions and relations of employment have an effect upon health; although, again, differences in material resources will exist between the groups. This classification is related to health outcomes and life expectancy. ${ }^{32}$

\section{Strengths and limitations}

Similar to the Erikson and Goldthorpe classification (see above)

\section{PROXY INDICATORS}

\section{Theoretical basis}

When direct measures of SEP are not available, some researchers use proxy indicators. These indicators can be strongly correlated with SEP and in some cases may provide insight into the mechanism that explains the underlying association of SEP and a particular health outcome (for example the association of number of siblings and respiratory infection). 


\section{Measurement}

Number of siblings has been used on the basis that in some contemporary industrialised societies larger numbers of children are associated with poorer SEP. ${ }^{33}$ This is not necessarily the case in other populations or societies. Number of siblings may have a direct effect on health outcomes as it may increase the risk of early life infection. However, it may also reflect other mechanisms through which family size can affect health outcomes in individuals and family members. For example, the positive association between parity and coronary heart disease among women may in part reflect family lifestyle resulting in obesity in all family members and in part reflect pathophysiological processes related to large numbers of pregnancies. ${ }^{35}$

Infant and maternal mortality rates have been used as ecological measures of an area or country SEP. ${ }^{36}$ Other characteristics such as maternal marital status, having a single mother or being an orphan, illegitimacy, broken family, and death of father or mother at an early age, are circumstances that often result in low SEP (for example, unemployment due to the inability of obtaining a flexible job and economic hardship can be associated with single motherhood). Several studies report worse health in these subgroups. ${ }^{37-40}$ However, adverse health outcomes could also be caused by other factors associated with these circumstances but unrelated to SEP. For example, infant and maternal mortality may reflect climate factors leading to infection diseases (for example, malaria infection) in addition to reflecting SEP; broken family, or death of mother/father at an early age, could lead to ill health due to depression.

\section{Strength and limitations}

These are not indicators of SEP in itself but because of their strong correlation they may provide valuable information when direct measures are not available. It is important to always consider alternative explanations of their association with health outcomes. In addition, their association with socioeconomic circumstances can differ depending on the context. For example, number of siblings may be a marker of lower SEP in some, although not all, industrialised societies and may not be related at all with SEP in other settings.

\section{WEALTH}

Wealth is a continuous measure that combines total assets and income (see housing and income in part 1 of the glossary). Its relation to health assumes that income in combination with total assets is a better measure of someone's socioeconomic circumstances and therefore a better predictor of health than income alone. In addition to income, wealth includes financial and physical assets such as the value of housing, cars, investments, inheritance or pension rights. ${ }^{16}$ The relative importance of wealth compared with income may change over the life course (wealth being more important in older age due to the accumulation of wealth and the impact of retirement on income ${ }^{41}$ ) or in population subgroups (for example, for a given level of income, African American and Hispanic households have less wealth than white households ${ }^{42}$ ).

\section{WORKING LIFE INDICATORS AND EXCLUSION FROM THE LABOUR MARKET}

People that cannot be classified in occupation based classifications can constitute a separate category. Unemployment can be used as an indicator based on exclusion from the workforce. Other work related indicators that can be used to measure SEP are job insecurity and type of employement. ${ }^{43}$ These conditions are associated with worse objective and subjective health through a variety of mechanisms, for example, lack of material resources for those who are unemployed, as well as social isolation, loss of self esteem, and the stress of potential job loss in conditions of job insecurity.

\section{COMPOSITE INDICATORS}

A number of composite measures have been used to assess SEP at the individual level. However, the increasing interest in determining more specific mechanisms for-rather than merely describing — socioeconomic inequalities in health, has lead to these measures being less frequently used. ${ }^{28}{ }^{44}$ On the other hand, composite indicators may be efficient when SEP is measured as a confounding factor rather than as the main exposure of interest, as these composite measures incorporate, and therefore, adjust for different aspects of SEP.

Individual studies have designed and used specific composite indices, often dependent on the data available to that particular study. This is most appropriate when SEP is a confounding variable of the association of interest or when the specific mechanisms determining inequalities are not the main focus of the study. Standard composite indicators are the following: Hollingshead index of social position, ${ }^{45}$ Duncan index, Nam-Powers socioeconomic status, Warner's index of status characteristics. $^{28}$ They have not been updated with current changes in the occupational structure and have not often been used in recent years. For more detailed explanations of these indicators we refer the reader to earlier reviews. ${ }^{28}$

\section{AREA LEVEL MEASURES (INDICES OF DEPRIVATION)}

Ecological, or area level, indicators are also used as measures of SEP. Most commonly these are aggregated from individual level or small area data, usually from census or other administrative databases. They can be used to characterise areas on a continuum from deprived to affluent (and are important for the allocation of public resources to areas) as well as a proxy for the SEP of the people living in those areas. In many studies one or more aggregate area measures, for example proportion of unemployed, proportion in blue collar or manual occupations, proportion with higher education in an area, are used with no attempt to combine measures into a composite score. In Britain a number of composite area level measures of SEP (referred to as indicators or indices of deprivation) have been developed for use in health related research and are increasingly used in other countries. The Townsend deprivation index is a measure of multiple deprivation using four variables from the (British) 1991 census: unemployment (defined as the proportion of economically active residents aged 16-64 who are unemployed), the proportion of households with no car, the proportion of households that are not owner occupied, and the proportion of households with overcrowding ( $>$ l person per room).$^{46}$ The Townsend score for each area is a summation of the standardised scores (z scores) for each variable; a greater score indicates higher levels of material deprivation. Other similar indices are the Carstairs deprivation index ${ }^{47}$ and the Jarman or underprivileged area (UPA) score. ${ }^{48}$

The Breadline Britain index has different conceptual origins. ${ }^{49}$ This is a consensual measure of poverty, based on what people themselves understand and experience as the minimum acceptable standard of living in contemporary Britain. Combining survey data with census data, and using weights to account for the different probability subgroups in the population have of suffering from a particular type of deprivation, ${ }^{50}$ this indicator is based on the proportions of: unemployment, people with no car, households non-owner occupied, lone parent households, households with persons with long term illness, unskilled and semi-skilled manual occupations ( social class IV and V) in an area. ${ }^{11}$ The Breadline Britain index thus includes a measure of health, and explorations of associations with health must take this into 
account (a version of the index without this component can be derived). The Breadline Britain index (modified version) has been found to have a close relation with the geography of mortality in Britain. ${ }^{51}$

Recently, Krieger and colleagues evaluated the performance of different area socioeconomic measures in capturing the association with cause specific mortality and cancer incidence in the USA. ${ }^{52}$ Interestingly, this work showed that among 11 single variable and eight composite measures it was "percentage of persons living below the US poverty line" that was best for use in surveillance of US socioeconomic differentials in mortality and cancer incidence. ${ }^{52}$ The authors reached similar conclusions regarding other health outcomes such as low birth weight, childhood lead poisoning, ${ }^{53}$ incidence of sexually transmitted diseases, tuberculosis, and non-fatal weapon related injuries. ${ }^{54}$

Area based indicators can be theorized as measures of the socioeconomic conditions of an area, and as such can have an independent influence on health. This idea is not new and in Britain has existed at least since Chadwick's time in the mid1800s. ${ }^{55}$ Increasing attention has been paid to the possibility that over and above individual characteristics, the place where a person lives can affect their health; "where" a person lives can be categorised as a neighbourhood, city, higher administrative areas (for example, health authority in the UK), region, or country. ${ }^{56} 57$ Various indicators presented in this glossary can be used to capture the characteristics of these different levels. Studies investigating "area effects" tend to find small associations relative to the size of individual SEP effects, and it remains unclear whether the associations between area level measures of socioeconomic circumstances and health outcomes are related to the socioeconomic characteristics of where people live, independently of the (lifetime) characteristics of the people living in these areas. ${ }^{57-60}$ This conceptual and empirical problem is especially pertinent when SEP is considered within a life course framework (see life course socioeconomic position below) and suggests historical information on both areas and individuals is required. The argument here is that adjustment for one single measure, which captures SEP at one point in time, is insufficient for capturing the full extent of individual effects. ${ }^{61}$ An additional problem is that few area level indicators were conceptualised to measure area characteristics, and as we have noted above, they are usually formed from aggregates of individual level data.

Area measures are also used as proxies for individual level indicators when these are not available. In this case, given the misclassification of individual socioeconomic circumstances when measured by area characteristics, the association with health outcomes is likely to be underestimated. ${ }^{62}$ The larger the areas the greater the misclassification will be. In addition, the variability in SEP picked up by the area level indicators will always be smaller than that of the individual level indicator, that is, the lowest value in area income will always be higher than the lowest individual income, and the other way around for the highest income. ${ }^{63}$ However, if area characteristics have an independent effect on health outcomes, the association of individual SEP will be overestimated when area level indicators are used instead to predict individual level effects. Whether under or overestimation affects a given study will depend on the health outcomes under study, the area measures, and area size of every specific context. ${ }^{4462}$

\section{LIFE COURSE SOCIOECONOMIC POSITION}

Socioeconomic circumstances are a changing but ever present backdrop to all stages of the life course and thus it is important to think about SEP as a time varying exposure. There is increasing evidence that adverse SEP in early life, independently of adult SEP, is a strong predictor of adult illness. ${ }^{616465}$ The indicators presented in the first part of this glossary, in addition to measuring different conceptual dimensions of SEP, can also capture information on SEP at different points in a person's life. ${ }^{66}$ Therefore, a combination of these can be used to measure SEP at different times over the life course (see figure 1 in the first part of the glossary).

Several prospective studies report higher mortality among those who experience adverse socioeconomic position at different periods of the life course. A variety of mechanisms may explain these associations.$^{67}$ For example, infection with Helicobacter pylori during childhood plausibly explains the association between childhood deprivation and stomach cancer, ${ }^{68}$ and suggests a critical period model for this health outcome. ${ }^{67}$ On the other hand, coronary heart disease, ischaemic stroke, and chronic obstructive pulmonary disease seem to be influenced by factors acting across the entire life course and therefore may conform more to a cumulative risk model. ${ }^{69-73}$ There is however an intrinsic problem in disentangling different life course processes (similar to differentiating age, cohort, and period effects).$^{74}$ Whether critical period, social mobility, accumulation of risks or combinations of these underlie the association between SEP and a given health outcome requires prior knowledge of the specific causal mechanisms. ${ }^{74}$

As the cumulative life course effect of adverse SEP on adult disease outcomes become more apparent, the need to adjust for different measures of SEP from across the life course in observational studies of exposures and outcomes that are strongly socially patterned is increasingly acknowledged. ${ }^{75}$ It is unlikely that residual socioeconomic confounding can be ruled out by simple adjustment for one or perhaps two measures of SEP at a single point in time. ${ }^{76}$

\section{CONCLUDING REMARKS}

SEP is key to understanding inequalities in health and is best considered as an umbrella term for a range of indicators and interconnected concepts. Individually and in aggregate, across the life course, time and place, a vast number of studies have shown how socioeconomic disadvantage is related to poorer health. A descriptive approach to considering this body of research emphasises the consistency of the associations and invokes ideas of "fundamental cause" and the "general susceptibility"79 of the disadvantaged. However, an aetiological framework needs to focus on the specificity of these associations. ${ }^{73}$ The departure point for a more complete aetiological understanding of socioeconomic health differentials should be based on mechanistic specificity of links between particular SEP indicators (as described above) and different health outcomes. This approach seems fruitful in developing greater insights into the mechanisms that generate socioeconomic inequalities in health, in different places and times. ${ }^{73} 80$

\section{Authors' affiliations \\ B Galobardes, M Shaw, D A Lawlor, G Davey Smith, Department of Social Medicine, University of Bristol, Bristol, UK \\ M Shaw, South West Public Health Observatory, UK \\ J W Lynch, Department of Epidemiology, School of Public Health and Center for Social, Epidemiology and Population Health, University of Michigan, USA}

Funding: the work of JWL and GDS is supported (in part) by a Robert Wood Johnson Foundation Investigators Award in Health Policy Research. Funds from this award also partly support BG. MS is funded by the South West Public Health Observatory. DAL is funded by a UK Career Scientist Award. The views expressed in this paper are those of the authors and not necessarily any funding bodies.

Conflicts of interest: none declared. 


\section{REFERENCES}

1 Rose M. Official social classifications in the UK. Guildford: University of Surrey, 1998

2 Prandy K. Class, stratification and inequalities in health: a comparison of the registrar-general's social classes and the Cambridge scale. Sociology Health and Illness 1999;21:466-84.

3 Chandola T, Jenkinson C. The new UK National Statistics socio-economic classification (NS-SEC); investigating social class differences in self-reported health status. J Public Health Med 2000;22:182-90.

4 Chandola T. Social inequality in coronary heart disease: a comparison of occupational classifications. Soc Sci Med 1998;47:525-33.

5 Erikson R, Goldthorpe JH. The constant flux. Oxford: Clarendon Press, 1992.

6 Mackenbach JP, Kunst AE, Cavelaars AE, et al. Socioeconomic inequalities in morbidity and mortality in western Europe. The EU Working Group on Socioeconomic Inequalities in Health. Lancet 1997;349:1655-9.

7 Kunst AE, Groenhof F, Mackenbach JP, et al. Occupational class and cause specific mortality in middle aged men in 11 European countries: comparison of population based studies. EU Working Group on Socioeconomic Inequalities in Health. BMJ 1998;316:1636-42.

8 Mackenbach JP, Bos V, Andersen O, et al. Widening socioeconomic inequalities in mortality in six Western European countries. Int J Epidemiol 2003:32:830-7.

9 Davey Smith G, Harding S. Is control at work the key to socioeconomic gradients in mortality? Lancet 1997;350:1369-70.

10 Rose D, O'Reilly K. The ESRC review of government social classifications. London: Office for National Statistics, 1998.

11 Krieger N, Williams DR, Moss NE. Measuring social class in US public health research: concepts, methodologies, and guidelines. Annu Rev Public Health 1997; 18:341-78

12 Muntaner C, Borrell C, Benach J, et al. The associations of social class and social stratification with patterns of general and mental health in a Spanish population. Int J Epidemiol 2003;32:950-8.

13 Wright EO. Classes. London: New Left Books, 1985.

14 Krieger N, Chen JT, Selby JV. Comparing individual-based and householdbased measures of social class to assess class inequalities in women's health: a methodological study of 684 US women. J Epidemiol Community Health 1999;53:612-23.

15 Wright EO. Class counts. Comparability studies in class analysis. Cambridge: University Press, 1997

16 Muntaner C, Eaton WW, Diala C, et al. Social class, assets, organizational control and the prevalence of common groups of psychiatric disorders. Soc Sci Med 1998:47:2043-53.

17 Muntaner C, Wolyniec P, McGrath J, et al. Psychotic inpatients' social class and their first admission to state or private psychiatric Baltimore hospitals. Am J Public Health 1994;84:287-9.

18 Schwalbe ML, Staples CL. Class position, work experience, and health Int J Health Serv 1986;16:583-602.

19 Wohlfarth T. Socioeconomic inequality and psychopathology: Are socioeconomic status and social class interchangeable? Soc Sci Med 1997:45:399-410

20 Wohlfarth T, van den BW. Social class and substance use disorders: the value of social class as distinct from socioeconomic status. Soc Sci Med 1998;47:51-8.

21 Macleod J, Davey Smith G, Metcalfe C, et al. Is subjective social status a more important determinant of health than material circumstances? Evidence from male workers occupying contradictory class locations in a prospective observational study of Scottish men. Soc Sci Med 2005;61:1916-29.

22 Lombardi C, Bronfman M, Facchini LA, et al. Operationalization of the concept of social class in epidemiologic studies [Operacionalizacao do conceito de classe social em estudos epidemiologicos]. Rev Saude Publica 1988;22:253-65

23 Horta BL, Victora CG, Menezes AM, et al. Environmental tobacco smoke and breasffeeding duration. Am J Epidemiol 1997; 146:128-33.

24 Dickman PW, Auvinen A, Voutilainen ET, et al. Measuring social class differences in cancer patient survival: is it necessary to control for social class differences in general population mortality? A Finnish population-based study. $J$ Epidemiol Community Health 1998:52:727-34

25 Domingo SA, Marcos AJ. Proposal of an indicator of "social class" based on the occupation [Propuesta de un indicador de la "clase social" basado en la ocupacion]. Gac Sanit 1989;3:320-6.

26 Marmot MG, Davey Smith G, Stansfeld S, et al. Health inequalities among British civil servants: the Whitehall II study. Lancet 1991;337:1387-93.

27 Abramson JH, Gofin R, Habib J, et al. Indicators of social class. A comparative appraisal of measures for use in epidemiological studies. Soc Sci Med 1982;16:1739-46

28 Liberatos P, Link BG, Kelsey JL. The measurement of social class in epidemiology. Epidemiol Rev 1988;10:87-121.

29 Sorlie PD, Backlund E, Keller JB. US mortality by economic, demographic, and social characteristics: the national longitudinal mortality study. Am J Public Health 1995:85:949-56.

30 Diez-Roux AV, Nieto FJ, Tyroler HA, et al. Social inequalities and atherosclerosis. The atherosclerosis risk in communities study. Am J Epidemiol 1995;141:960-72.

31 Chandola T, Jenkinson C. Social class differences in morbidity using the new UK National Statistics socio-economic classification. Do class differences in employment relations explain class differences in health? Ann N Y Acad Sci 1999:896:313-15.

32 Bartley M. Health inequality: an introduction to theories, concepts and methods. Cambridge: Polity Press, 2004.
33 Wamala SP, Lynch J, Kaplan GA. Women's exposure to early and later life socioeconomic disadvantage and coronary heart disease risk: the Stockholm female coronary risk study. Int J Epidemiol 2001;30:275-84.

34 Hart CL, Davey Smith G. Relation between number of siblings and adult mortality and stroke risk: 25 year follow up of men in the collaborative study. $J$ Epidemiol Community Health 2003;57:385-91.

35 Lawlor DA, Emberson JR, Ebrahim S, et al. Is the association between parity and coronary heart disease due to biological effects of pregnancy or adverse lifestyle risk factors associated with child-rearing? Findings from the British women's heart and health study and the British regional heart study. Circulation 2003;107:1260-4.

36 Forsdahl A. Are poor living conditions in childhood and adolescence an important risk factor for arteriosclerotic heart disease? Br J Prev Soc Med 1977;31:91-5

37 Modin B. Born out of wedlock and never married--it breaks a man's heart. Soc Sci Med 2003;57:487-501

38 Osler M, Andersen A-MN, Due $P$, et al. Socioeconomic position in early life birth weight, childhood cognitive function, and adult mortality. A longitudinal study of Danish men born in 1953. J Epidemiol Community Health 2003;57:681-6.

39 Lundberg 0 . The impact of childhood living conditions on illness and mortality in adulthood. Soc Sci Med 1993;36:1047-52.

40 O'Leary SR, Wingard DL, Edelstein SL, et al. Is birth order associated with adult mortality? Ann Epidemiol 1996;6:34-40.

41 Lynch J. Social position and health. Ann Epidemiol 2001;6:21-3.

42 Smith JP. Racial and ethnical differences in wealth in the health and retirement study. J Hum Resources 1995;30(suppl):S158-83.

43 Benavides FG, Benach J, Diez-Roux AV, et al. How do types of employment relate to health indicators? Findings from the second European survey on working conditions. J Epidemiol Community Health 2000;54:494-501.

44 Geronimus AT, Bound J. Use of census-based aggregate variables to proxy for socioeconomic group: evidence from national samples. Am J Epidemiol 1998; 148:475-86.

45 Hollingshead BA, Redlick FC. Social class and mental illness. New York: Wiley, 1958.

46 Townsend $\mathrm{P}$, Phillimore $\mathrm{P}$, Beattie A. Health and deprivation: inequality in the North. London: Croom Helm, 1988.

47 Carstairs V, Morris R. Deprivation and mortality: an alternative to social class? Community Med 1989;11:210-19.

48 Jarman B. Identification of underprivileged areas. BMJ 1983;286:1705-9.

49 Gordon D, Pantazis C. Breadline Britain in the 1990s. Aldershot: Ashgate, 1997.

50 Gordon D. Census based deprivation indices: their weighting and validation. $J$ Epidemiol Community Health 1995;49:S39-44.

51 Shaw M, Dorling D, Gordon D, et al. The widening gap. Bristol: The Policy Press, 1999.

52 Krieger N, Chen JT, Waterman PD, et al. Geocoding and monitoring of US socioeconomic inequalities in mortality and cancer incidence: Does the choice of area-based measure and geographic level matter? The Public Health Disparities Geocoding Project. Am J Epidemiol 2002:156:471-82.

53 Krieger N, Chen JT, Waterman PD, et al. Choosing area based socioeconomic measures to monitor social inequalities in low birth weight and childhood lead poisoning. The Public Health Disparities Geocoding Project (US). J Epidemiol Community Health 2003:57:186-99.

54 Krieger N, Waterman PD, Chen JT, et al. Monitoring socioeconomic inequalities in sexually transmitted infections, tuberculosis, and violence: geocoding and choice of area- based socioeconomic measures - the public health disparities geocoding project (US). Public Health Rep 2003:118:240-60.

55 Wohl AS. Endangered lives; public health in Victorian Britain. London: Dent, 1983.

56 Tunstall HVZ, Shaw M, Dorling D. Places and health. J Epidemiol Community Health 2004:58:6-10.

57 Diez Roux AV. A glossary for multilevel analysis. J Epidemiol Community Health 2002;56:588-94.

58 Macintyre S, Ellaway A, Cummins S. Place effects on health: how can we conceptualise, operationalise and measure them? Soc Sci Med 2002;55:125-39.

59 Reijneveld SA, Pearl M, Pickett KE. Explanations for differences in health outcomes between neighbourhoods of varying socioeconomic level. J Epidemiol Community Health 2001;55:847.

60 Pickett KE, Pearl M. Multilevel analyses of neighbourhood socioeconomic context and health outcomes: a critical review. J Epidemiol Community Health 2001;55:111-22.

61 Davey Smith G, Hart C, Blane D, et al. Lifetime socioeconomic position and mortality: prospective observational study. BMJ 1997;314:547-52.

62 Davey Smith G, Hart CL, Watt G, et al. Individual social class, area-based deprivation, cardiovascular disease risk factors, and mortality: the Renfrew and Paisley study. J Epidemiol Community Health 1998;52:399-405

63 Davey Smith G, Ben-Shlomo Y, Hart C. Re: "Use of census-based aggregate variables to proxy for socioeconomic group: evidence from national samples". Am J Epidemiol 1999;150:996-7.

64 Davey Smith G, Lynch JW. Socioeconomic differentials. In: Kuh D, BenShlomo Y, eds. A lifecourse approach to chronic disease epidemiology. 2nd ed. Oxford: Oxford University Press, 2004.

65 Beebe-Dimmer J, Lynch JW, Turrell G, et al. Childhood and adult socioeconomic conditions and 31-year mortality risk in women. Am J Epidemiol 2004;159:481-90. 
66 Kuh D, Ben Shlomo Y, Lynch J, et al. Life course epidemiology. J Epidemiology Community Health 2003;57:778-83.

67 Ben Shlomo Y, Kuh D. A life course approach to chronic disease epidemiology: conceptual models, empirical challenges and interdisciplinary perspectives. Int J Epidemiol 2002;31:285-93.

68 Stemmermann GN, Fenoglio-Preiser C. Gastric carcinoma distal to the cardia: a review of the epidemiological pathology of the precusors to a preventable cancer. Pathology 2002;34:494-503.

69 Davey Smith G, Hart C, Blane D, et al. Adverse socioeconomic conditions in childhood and cause specific adult mortality: prospective observational study. BMJ 1998;316:1631-5.

70 Lawlor DA, Ebrahim S, Davey Smith G. Socioeconomic position in childhood and adulthood and insulin resistance: cross sectional survey using data from British women's heart and health study. BMJ 2002;325:805-7.

71 Lawlor DA, Ebrahim S, Smith GD. The association of socio-economic position across the life course and age at menopause: the British women's heart and health study. Br J Obstet Gynaecol 2003; 110:1078-87.

72 Lawlor DA, Smith GD, Ebrahim S. Association between childhood socioeconomic status and coronary heart disease risk among postmenopausal women: findings from the British women's heart and health study. Am J Public Health 2004;94:1386-92.
73 Galobardes B, Lynch JW, Davey Smith G. Childhood socioeconomic circumstances and cause-specific mortality in adulthood: systematic review and interpretation. Epidemiol Rev 2004;26:7-21.

74 Hallqvist J, Lynch J, Bartley M, et al. Can we disentangle life course processes of accumulation, critical period and social mobility? An analysis of disadvantaged socio-economic positions and myocardial infarction in the Stockholm heart epidemiology program. Soc Sc Med 2004;58:1555-62.

75 Davey Smith G, Ben-Shlomo Y, Lynch JW. Life course approaches to inequalities in coronary heart disease risk. In: Stansfeld SA, Marmot MG, eds. Stress and the heart. London: BMJ Books, 2002.

76 Lawlor DA, Davey Smith G, Kundu D, et al. Those confounded vitamins: what can we learn from the differences between observational versus randomised trial evidence? Lancet 2004;363:1724-7.

77 Link BG, Phelan J. Social conditions as fundamental causes of disease. J Health Soc Behav 1995;(special no):80-94

78 Link BG, Phelan JC. Understanding sociodemographic differences in healththe role of fundamental social causes. Am J Public Health 1996;86:471-2.

79 Syme SL, Berkman LF. Social class, susceptibility and sickness. Am J Epidemiol 1976;104:1-8.

80 Davey Smith G. Health inequalities: lifecourse approaches. Bristol: Policy Press, 2003.

\section{THE JECH GALLERY}

\section{Love pounds, tons of inequities}

$\mathrm{N}$

$\mathrm{ws}^{1}$ alerted to El Salvador in 2004: in four decades young people died for the first time by hunger. It was an announced death: the undernutrition, reemergent disease is a direct consequence of the neoliberal era, and has deepened. The suppression of the agricultural subsidies annihilated food security and the subsistence cultures of poor farmers. The minimum wage was frozen to compete with low production costs, in the globalised market of the textile manufacturing. An economy dominated by dollars and an increasing cost of the basic basket, especially foods, completed the picture. These factors featured heavily in a report of the Office of the Judge Advocate General for the Defence of the Human Rights. ${ }^{2}$ The answer: an assisted programme of nutritional consultation and food distribution called "Pounds of love". ${ }^{3}$ But the inequities, exacerbated by unequal international trade relations, unjust distribution of the wealth, unemployment, payments in the public health system, and poor social investment continue to grow and generate poverty, social violence, and insanity to a rate that soon will end in the inability to govern.

Correspondence to: Dr E Espinoza, Final 25

Avenida Norte y Boulevard de Los Héroes Edificio de la Rectoría, San Salvador, E Salvador; espinoza@telesal.net

\section{REFERENCES}

1 Anonymous. Mueren 40 niños por desnutrición en Tacuba. La Prensa Gráfica 2004:17 Feb.

2 Office of the Judge Advocate General. Informe especial de la Señora Procuradora sobre Situación de Desnutrición Infantil en Zonas Rurales del Occidente del País. Procuraduría para la Defensa de los Derechos Humanos, San Salvador, El Salvador. http://www.pddh.gob. sv/modules . php? name $=$ Downloads

3 Libras de Amor. http://www.librasdeamor.org/ home.html.

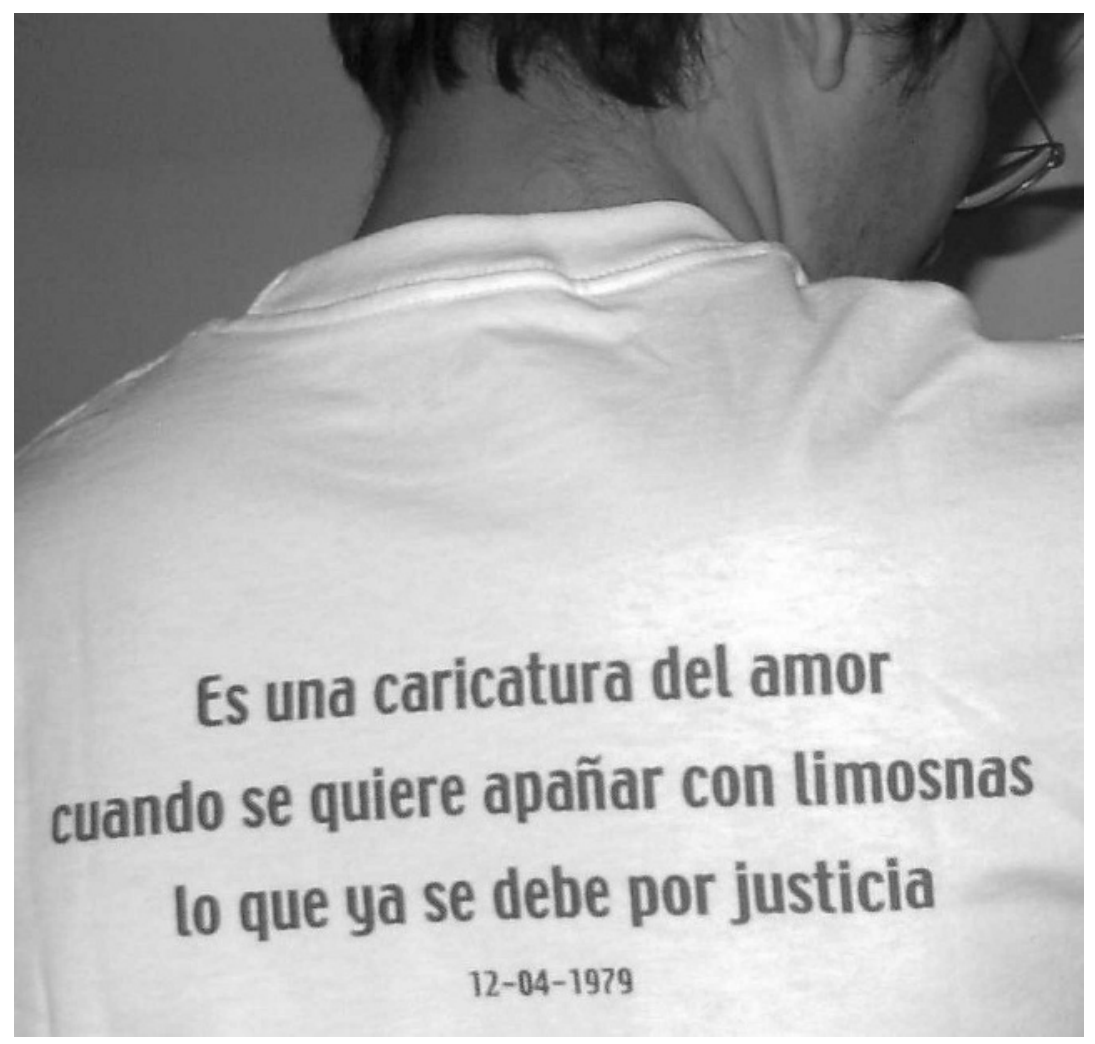

A tee shirt legend on the 25 year anniversary of the murder of Archbishop Oscar Romero- "It is a cartoon of love when it is wanted to patch up with gifts that which is already owed by justice" (Taken from the 12 April 1979 homily of the Archbishop Romero whose assassination in 1980 unleashed a civil war of 12 years in El Salvador). 